\title{
O KRIZI IN ODGOVORNOSTI
}

Živimo v obdobju, ki tako ali drugače nasilno posega $v$ naše predstave o življenju, ki ga želimo živeti, o socialni državi, o razvoju za jutri. Kriza tam in kriza tu, čisto blizu. Iz besed politikov, makroekonomistov, sociologov se je prelevila $v$ niz ukrepov tukaj in zdaj, ki enkrat posežejo v štipendijo naših otrok, drugič se znajdejo na plačilni listi, tretjič posežejo v sosedin varstveni dodatek, svakova zaposlitev, ki je bila še včeraj tako dobra in trdna, je odšla neznano kam. Zdi se, da se kot domine podira naša varnost, tista materialna in tista osebna, ko smo zaupali tistim, ki so imeli v svojih rokah vzvode družbenega razvoja, pa tudi v lastne zmožnosti, da bomo z učenjem, delom, prizadevnostjo prej ali slej dosegli zastavljene cilje. Danes se zaupanje $v$ druge nevarno maje, hkrati pa imamo občutek, da sami prav zaradi stvari, ki se dogajajo okoli nas, ne bomo zmogli.

Te stiske in samospraševanja posegajo tudi na naše profesionalno področje. Vsi, ki delamo v izobraževanju odraslih oziroma izobraževanju nasploh, svoj profesionalni etos gradimo na veri $v$ sposobnosti posameznika, na prepričanju o posameznikovem in družbenem razvoju, podprtem s kakovostnim znanjem. $V$ tem vidimo tudi svoje poslanstvo - odpirati ljudem poti do znanja, jih pri tem strokovno usmerjati, podpirati in spodbujati.

V tem nas je v zadnjih desetletjih (če ne grem globlje v zgodovino) dobro podprla tudi politika. Spomnimo se samo dveh dokumentov, ki sta bila svetovno odmevna in sta $v$ marsičem posegla $v$ naše vsakdanje profesionalno vedenje in delovanje. Prvi tak dokument je Poročilo mednarodne komisije o izobraževanju za enaindvajseto stoletje, pripravljeno leta 1996 za UNESCO, ki je nastalo s sodelovanjem mednarodno priznanih znanstveni-

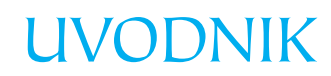

kov in pod vodstvom francoskega ekonomista in politika J. Delorsa. Takole je zapisano $v$ tem dokumentu: »Nova, razširjena zasnova učenja bi morala vsakemu posamezniku omogočati, da odkrije, predrami in obogati svojo ustvarjalnost - da spravi na dan zaklad, ki se skriva v vsakem izmed nas. «(Delors, 1996: 78.) To naj bi dosegli z razvijanjem štirih »stebrov « izobraževanja: učiti se, da bi vedeli; učiti se, da bi znali delati; učiti se, da bi znali živeti v skupnosti; in učiti se, da bi znali biti in živeti s seboj. O tem poročilu je napisanih nešteto razprav, zelo veliko je strokovnih del, ki se naslanjajo na njegova sporočila; prav gotovo smo ga vsi, ki delamo v izobraževanju, prebrali in premislili ter ga tako ali drugače vpeli v svoja ravnanja. Rečemo lahko, da so bila sporočila tega dokumenta skladna z našim temeljnim profesionalnim prepričanjem o zmožnosti posameznika, da se razvija, in to vse življenje, in našo strokovno zavezo, da posamezniku odpiramo priložnosti, da razvije svoje sposobnosti. Za izobraževalce odraslih je bilo poročilo še posebej pomembno, saj je na politični ravni utemeljilo koncept vseživljenjskega učenja, v katerega smo, četudi včasih z drugimi besedami, verjeli že dolgo prej. To, kar je prav za izobraževanje odraslih še posebnega pomena, pa je bila potrditev, da ni samo ene poti do znanja, temveč je poti lahko več; ni za vse primerna ista pot, temveč tista, ki posamezniku omogoči, da pridobi želeno znanje. Znanje, pridobljeno na različne načine, ima enako vrednost; znanje, pridobljeno $v$ šoli, ni več vredno kot znanje, pridobljeno na drugačen način v odrasli dobi. Skratka, šlo je za dokument, ki je na politični ravni konceptualno opredelil razvoj izobraževalnih sistemov vsega sveta $-z$ upoštevanjem njegovih smernic naj bi se človeřtvo uspešno spopadalo z izzivi 21. stoletja. 
Drugi dokument je bolj »evropske narave", čeprav je imel tudi globalni vpliv. Gre za Lizbonsko deklaracijo, sprejeto na zasedanju Evropskega sveta v Lizboni leta 2000, v kateri so voditelji držav in vlad EU opredelili, »da bo postalo evropsko gospodarstvo do leta 2010 najbolj konkurenčno in dinamično, na znanju temelječe gospodarstvo na svetu, sposobno trajnostne gospodarske rasti $s$ številčnejšimi in boljšimi delovnimi mesti ter $z$ večjo socialno kohezijo « (sklepi predsedstva, Evropski svet v Lizboni, 23. in 24. marca 2000), »in trajnostno glede okolja « (srečanju na vrhu v Göteborgu 2001). S tem je bil postavljen izziv in hkrati prižgana zelena luč razvoju izobraževanja v Evropi, iskanju novih, boljših poti in prijemov, vlaganju $v$ izobraževanje, poudarjanju ter merjenju njegove kakovosti. Na podlagi Lizbonske deklaracije je nastala cela vrsta političnih dokumentov, ki so natančneje opredeljevali cilje in smernice razvoja $v$ posameznih delih izobraževalnega sistema, tudi na področju razvoja izobraževanja odraslih. Izobraževalci smo politični cilj Lizbonske deklaracije nekako posvojili - priznajmo si, da smo ta $v$ 90. letih verjetno eden izmed najbolj pogosto citiranih stavkov nemalokrat oznanjali na svojih strokovnih konferencah, $v$ strokovnih pogovorih, člankih. To tudi ni čudno, saj je $v$ temelju utrjeval pomen našega poslanstva - znanje je tisto, ki zagotavlja osebni in družbeni razvoj, izobraževalci pa smo tisti, ki lahko pripomoremo, da bo tega znanja več in bo bolj kakovostno.

Če odmislimo bolj redke skeptike in leta streznitve, ki so prišla že kmalu po letu 1995 , lahko rečemo, da je družbo in posameznike prevevala vera $v$ moč znanja, ki odpira vse poti, posamezniku pa ne glede na njegov izvor in druge okoliščine možnosti za polno in ustvarjalno življenje. Ta vera $v$ znanje se je kazala tudi $v$ čisto praktičnih ukrepih. Če se omejim na Slovenijo, je bil to čas pospešenega in prednostnega vlaganja $v$ znanost in izobraževanje, krepila se je mreža šol in drugih izobraževalnih organizacij, ustanavljale so se zasebne izobraževalne organizacije za tiste, ki so želeli drugače in še nekaj drugega, kot ponujajo javne šole, spodbujalo se je čim bolj zahtevno splošno izobraževanje (gimnazije), razvijale so se nove oblike učenja (študijski krožki, središča za samostojno učenje, izobraževalna dejavnost knjižnic, univerza za tretje življenjsko obdobje itd.), več se je vlagalo $v$ profesionalni razvoj izobraževalcev itd.

In potem je prišla kriza - globalna, ekonomska, politična in družbena. Pretresa nas globoko, ni ji videti konca. Tajkuni, banke, neplačana posojila, stečaji, bankroti držav, nižanje bonitetnih ocen držav (Slovenije) - besednjak, ki ga pred desetletjem (skoraj) nismo poznali, nas preplavlja. EU $n i$ vodilno gospodarstvo $v$ svetu, svetovni razvoj ni v vzponu, temveč svet pretresajo velike krize. Ali to pomeni, da izobraževalci nismo uresničili svojega poslanstva, da bi poskrbeli za več znanja, ki naj bi bil generator razvoja?

Pa se vprašajmo: ali je izobrazbena raven prebivalstva višja kot pred dvema desetletjema? Je. Ali smo zmanjšali osip na vseh ravneh izobraževanja in tako večino posameznikov pripeljali vsaj do osnovnega poklica? Smo. Ali smo mlade usposobili za delo na svetovnem trgu? Smo. Ali smo omogočili učenje odraslim, tako za njihovo spopolnjevanje $v$ poklicu kot za njihov osebni razvoj? Smo. Smo poskrbeli za raznolikost načinov izobraževanja in učenja? Smo. Smo bili posebej pozorni na ranljive skupine prebivalstva in smo poiskali načine, ki so tudi njim približale svet učenja? Smo. Smo poskrbeli za pretok znanja? Smo. Smo ...? Seveda ima vsak»smo«lahko tudi nadaljevanje: Smo, lahko pa bi še to in to, še več, še drugače ..., a ni mogoče zanikati, da je napredek, če gledamo rezultate in učinke izobraževanja $v$ zadnjih dveh desetletjih, opazen. 
Morda prav zato še nisem zasledila, da bi kdo rekel: „Glejte, motili smo se, vec znanja ne pomeni več blaginje, znanje ne zagotavlja družbene in posameznikove uspešnosti. Kaj nam pomaga, da imamo več diplomantov, magistrov in doktorjev znanosti, da ima velika večina ljudi vsaj poklicno izobrazbo?" A vendarle se mi $z d i$, da je ta misel nekje v ozadju. Ste v zadnjem času slišali politika, ki bi zahteval še bolj pospešeno vlaganje $v$ znanost in razvoj, ki bi izražal zaskrbljenost nad številom manj izobraženih, nad osipniki, ki bi ga skrbela raven kakovosti javnega izobraževanja ...? In bi vse to povezoval z možnostjo izhoda iz krize? Ali ki bi na primer omenil Delorsovo poročilo ali Lizbonsko deklaracijo in problem, da ciljem takih dokumentov nismo sledili ali jih ne uresničevali dovolj resno? Jaz že ne. Slišimo pa vsak dan o novih idejah o krčenju javne porabe, kamor sodi tudi izobraževanje - to je zdaj pot rešitve. Bolje nam bo, če nam bo uspelo $v$ razrede strpati nekaj več otrok ali odraslih - tako bomo potrebovali manj učiteljev, manj sredstev bo šlo za njihove plače. Nasploh so preveč zaslužili. Zakaj potrebujemo javne izobraževalne ustanove tako rekoč $v$ vsaki vasi? Javne univerze imajo preveč avtonomije in denarja, diplomantov pa je tako ali tako preveč, saj jih je znaten delež na zavodu za zaposlovanje. Zakaj bi iz javnih sredstev plačevali šolnine odraslim, ki so že imeli priložnost za učenje, pa je niso izkoristili? Zakaj bi po nepotrebnem zviševali standard izobraževanja mladine s štipendijami in malicami? Kaj nam bodo razvojna in raziskovalna jedra na različnih ravneh izobraževalnega sistema (ACS in drugi javni zavodi), če lahko to veliko ceneje naredi ena sama ustanova? In niti nas ne slepijo, da bo tako privarčevani denar namenjen denimo vlaganju v najzahtevnejše projekte na področju izobraževanja, ne, namenjen je za nekaj drugega, kaj jaz vem, za pokrivanje »skrivnostnih lukenj« v bankah?!
Kaj lahko storimo izobraževalci? Najslabše bi bilo, če bi se prepustili malodušju in defetizmu, da se ne da nič storiti, da o vsem odločajo drugi. Ali še slabše, da bi s tem prevzemali krivdo za stvari, povezane z izobraževanjem, na katere pa nimamo vpliva. Ali se počutili krive, ker smo porabniki javnega denarja. Ne trdim, da ni primerno, da se v tem trenutku sindikalno ali politično udejstvujemo, da bi z argumenti poskušali ovreči preveliko lomastenje v škodo področju. $\mathrm{Ob}$ tem ali tudi brez tega pa čas zahteva od nas še bolj angažirano strokovno udejstvovanje, analiziranje, razmišljanje in delovanje. Imamo odgovornost do učečih se in tistih, ki znanje potrebujejo. Kriza je, tako kot za druge, tudi za nas priložnost za spraševanje, ali smo naredili vse oziroma kaj lahko še storimo.

$V$ prvi vrsti nosimo odgovornost do ljudi, ki potrebujejo znanje. Ta odgovornost se najzahtevneje odraža v primerih, ko posamezniki pomena znanja sploh ne cenijo ali ga ne znajo vrednotiti. Tudi vas je morda zabolela izjava kakega brezposelnega, včasih slišana na TV, čě̌, kaj mi bo ta in ta tečaj, moji otroci so lačni, potrebujem službo! S takimi situacijami se bomo zdaj še pogosteje srečevali: več je (bo) brezposelnih, večje bodo socialne stiske, izobraževanje pa je sredstvo za dosego ciljev nekje $v$ prihodnosti. In ta prihodnost je zdaj še veliko bolj negotova: prav nobenega jamstva ni, da bodo zaposlitve v nekem poklicu čez toliko in toliko let sploh mogoče; mi sami na razmere na trgu dela nimamo vpliva niti ne obstajajo verodostojne študije, $k i$ bi nam jasneje predstavile mogoče situacije $v$ prihodnosti. Zato je za nas strokovni izziv zbujanje motivacije za izobraževanje pri tistih, ki $v$ znanju ne vidijo izhoda ali vrednote, danes še toliko večji - kako ljudi s pomanjkljivo ali neustrezno izobrazbo kljub stiskam, ki jih doživljajo, in problemom, ki jih morajo rěsevati danes, prepričati, da naj ob tem vlagajo tudi v svoje znanje, da bodo imeli v prihodnosti več priložnosti. 
To, kar še moramo narediti, pa je, da skrbno analiziramo svojo izobraževalno ponudbo in ne ponujamo programov za poklice, $k i$ so že danes suficitarni, pa četudi je povpraševanje po njih danes še vedno zadostno. Morda je izziv za izobraževalce odraslih motiviranje za strokovno usposabljanje $v$ poklicih, ki niso visoko na družbeni lestvici vrednot, a dajejo posamezniku ekonomsko varnost. Programe, ki jih na novo razvijamo, skrbno pretehtajmo, analizirajmo možnosti zaposlitve, ne pa, da diplomantom prepuščamo, da se bodo z novim poklicem ali znanjem že kako znašli. To je naša odgovornost! Ponovno in vedno znova razmišljajmo o vednotah, ki bi jih bilo treba ponujati v programih - tistih za danes in še bolj za jutri. Ob tem ne pozabimo, katere vrednote kaže z izobraževanjem še bolj podpirati - to je morda polje, o katerem smo $v$ preteklosti premalo razmišljali in govorili.

Naša odgovornost zadeva tudi tiste, ki izražajo željo po učenju, a so jim poti do znanja zaprte. Tudi takih bo s poglabljanjem krize vse več, saj bo pot do znanja mnogim postala tudi ekonomsko nedosegljiva. Seveda izobraževanja ne moremo izvajati brezplačno, a prav gotovo mi bolj kot oni poznamo poti, ki so vseeno mogoče, ali pa bi jih znali poiskati. Ob ekonomski krizi bodo še bolj prizadeti ljudje iz najbolj ranljivih skupin (starejši, manj izobraženi, telesno ali duševno ovirani ...). Že v obdobju relativnega blagostanja so bile te skupine marsikdaj odrinjene na rob, še toliko hitreje bodo $v$ krizi. Njihovo izobraževanje »se ne bo splačalo«, bo »predrago«. Izobraževalci smo tisti, ki nanje ne smemo pozabiti; odgovorni smo, da iščemo poti zanje, da bo učenje dosegljivo tudi njim.

Naša odgovornost je tudi pospešeno vlaganje $v$ lastno znanje. Zahtevne razmere namreč zahtevajo zahtevnejše rešitve - našli jih bomo le $z$ dobrim znanjem in premišljenim delovanjem. Ni se mogoče skriti za trditev, da zaostrene razmere ne dopuščajo bolj kakovostnega dela - morda še bolj kličejo po iskanju dobrih rešitev, po doseganju dobrih učinkov, četudi ob poslabšanih materialnih možnostih.

Na zadnje mesto, a ne zato, ker je to najmanj pomembno, temveč zato, da to poudarim, bi dala našo strokovno odgovornost, da vse ukrepe, ki nam jih pripravljajo za »uravnoteženje financ" in zadevajo našo stroko, skrbno proučimo ter predlagateljem in javnosti predstavimo, kakšne posledice lahko pričakujemo ob njihovi uvedbi. Če so možne, pokažimo tudi alternative, ki so strokovno boljše. Včasih se zdi, da nas pri tem nihče ne sliši, da se zaletavamo ob zid in da tako početje nima smisla, toda teh ocen ne more dati nihče drug, ker za to ni strokovno usposobljen, in tudi to je naša odgovornost $v$ kriznih časih.

Ali se naše poslanstvo - odpirati ljudem poti do znanja, jih pri tem strokovno usmerjati, podpirati in spodbujati - spreminja? $\mathrm{Ne}$, postaja še bolj odgovorno.

\section{Sonja Klemenčič}

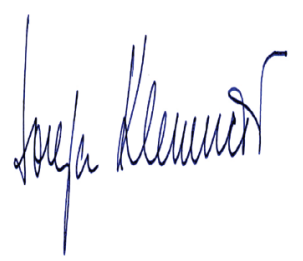

\section{LITERATURA}

Delors, J. (1996): Učenje: skriti zaklad. Ljubljana, Ministrstvo za šolstvo in šport.

Lizbonska deklaracija (2000). Dostopno na: http:// ue.eu.int/ueDocs/cms_Data/docs/pressData/en/ ec/00100-r1.en0.htm (8. 1. 2012) 